\title{
The Effect of Instruction Through Mobile Phone-Based Virtual Networks on the Learning Rate of Students with Visual Impairment
}

\section{| Zabihollah Allahi ${ }^{1}$ | Morteza Bakhtiarvand ${ }^{2}$ | | Maryam Rajabiyan Dehzireh ${ }^{3}$ |}

\author{
${ }^{1}$ Assistant professor, \\ department of educational \\ science, Farhangian \\ University, Zahedan, Iran \\ ${ }^{2,3}$ Ph.D.student of Educational \\ Technology, Department of \\ Educational Technology, \\ Faculty of Psychology and \\ Education, Allameh \\ Tabataba'i University, \\ Tehran,1489684511, Iran \\ ${ }^{1}{ }_{\text {zallhi57@yahoo.com }}$
}

\begin{abstract}
This study aims at investigating the effects of instruction using mobile phone based virtual networks on the rate of learning of students with visual impairment. This study utilized a quasiexperimental approach, which was performed among male students suffering from visual impairment in their second grade of high school in Iran. The sample size consisted of 52 students with visual impairment (26 in experimental group and 26 in control group) who had cell phones and volunteered to participate in the test. The experimental group was taught through WhatsApp social network while the control group received regular classroom teachings. The data was collected using a researcher made English language test. The findings of the study revealed that the instruction through the virtual networks has a positive effect on the increase of learning rate in students with visual impairment. The results from this study would be useful to instructional designers, specialists, special education teachers and learners who wish to use cell phones for the blind.

KEYWORDS
\end{abstract}

Mobile learning; mobile phone; WhatsApp; visually impaired.

\section{INTRODUCTION}

One major concern of the educational system is the proper and suitable method of instruction for students with visual impairment. In order to properly instruct visually impaired student, it is important to apply technologies that are suitable for the improvement of their performance and quality of learning which can be effective in creating and encouraging motivation among them and also empowering them (Sharifi Daramadi, 2000). Visual problems can affect student's motivation and abilities to engage in the process of learning (Sparrow Hawk and Hilde, Translated by Zaraii Zavaraki \& Velayati, 2014). One of the best solutions to these problems is using modern technologies such as mobile phones as one of the most efficient technologies that have integrated its place in various communities of the society, particularly among students diagnosed with visual impairment. The potential capabilities of mobile technology include ubiquity, low cost, familiarity and its availability (Druin, 2009). Its interactivity, games, access to social networks via wireless technologies (Sharples, 2000), no need to move out of a place, social presence with people who can see and cooperate with students groups can revolutionize the visually impaired learners' access to information and reduce or eliminate the effects of past difficulties that were common in the familiar educational environment. 
The researchers believe that interest in the use of mobile devices for mobile learning functionality is growing (Ally and Prieto-Blazquez, 2014; Kukulska-Hulme, Sharples, Milard, Arnedillo-Sánchez and Vavoula, 2009; Crompton, 2015 \& Preece, 2000). Empirical evidence reveals that teachers are interested in using mobile devices in their classrooms (Hodges and Prater2013). For instance, in the Unites States, seven out of elementary school students (71\%), two-thirds of secondary school students (67\%) and over half (56\%) of high school students said they would like to use mobile devices for learning (Pearson Education, 2014).

Mobile technologies especially mobile phones and their easy access for people particularly for students, has brought new opportunities in the learning environment (Jalilifar and Mashhadi, 2013). According to Guler, Kilic and Cavus (2014), mobile learning can be defined as a type of learning activity supported and distributed by the help of portable, wireless devices and mobile phone networks. Mobile technologies have a strong potential to enhance teaching and learning (Rikala, 2014). Thus, ownership and use of mobile devices, has become more widely spread (Gedik, Hanci-Karademirci, Kursun \& Cagiltay, 2012; Lee \& Nina, 2012; Mohammed, Mamat \& Isah, 2012). Through mobile technology, learners' access to information and educational materials, essentially as a result of their location, are not disturbed. Blind people value devices that help their independence and self-autonomy (Keating; Nagay; Hadder and Kowalsky, 2007) and mobile technology easily meets this need for them. In fact, students can interact with the use of mobile technologies that are accessible in different locations and in a variety of conditions (Prajapaty and Patel, 2014).

One of the functions of mobile phones to students with visual impairment is that it increases motivation and ability of the students to engage in school activities with other students (able to see and visually impaired). Mobile devices that contain learning content can support effective learning, provide any needed information at any time and place (Martin and Ertzberger, 2013), create cooperative learning opportunities (Chaung, 2015) and create change opportunities like focus of learning based on learner based teaching, cooperative, skill developing, higher level thought and learning for life (Alvarez, Alarcon \& Nussbaum 2011). Mobile learning eliminates the barriers between in and out of classroom experiences by providing the learning opportunities regardless of time, place and potentialities for students' engagement in instructional activities beyond the limits of traditional teaching environment (Martin, McGill \& Sudweeks, 2013).

According to Laurillard (2007) " mobile learning is an activity that is innately exciting for the students" since it provides them with control on learning objectives, ownership, joy, communication, learning in situation and continuity of contexts. Furthermore, Roblyer and Doering believes that, merging of new technologies in a way that is meaningful and in line with students' motives and objectives creates more motivation for learning. The ability to continue to learn without the limitation of time and space is an important element that affects the motivation of the students to use mobile practical applications (Lan and Sie, 2010). To guarantee full access to new communication technologies, the needs of people with visual impairment should be understood (Keating et al., 2007). Though the use of these technologies for people with special needs requires adaptation. The purpose of special education is to know the required steps in creating such adaptation (Zaraii Zavaraki and Jafarkhani, 2012). The investigations carried out in this research and theoretical literature especially on mobile phones reveals that, in most of the research that have been performed so far, the impact of mobile technologies for normal students have been studied and research on the impact of mobile technologies on the learning of students with visual impairment is very low, irrespective of the efficiency of mobile phones for students with visual impairment. 
Therefore, this study has examined the impact of mobile based virtual network on learning for students with visual impairment. More specifically, this study has addressed the following research questions: Then major research question: Does teaching the students by using mobile based virtual networks have any significant effect on learning for visually impaired students? Based on the above-mentioned research question, the following research hypothesis was formulated: Teaching through mobile based virtual networks has a significant effect on effective learning of visually impairment students.

\section{RESEARCH METHODS}

This study utilized a quasi-experimental method, pretest-posttest in which the control group was used. The present study involves an applied research, considering its purpose is to enhance the development of practical knowledge in a particular field. The statistic population that was selected for this study consisted of the entire male students $(\mathrm{N}=142)$ in the second grade of high school in Iran (based on the statistics collected from the Special Students Education System of Iran) and who were engaged in education in 2014-2015were all blind students. In the present study, due to the legal limitations of the Education System in conducting a research by application of mobile phones in the communities of feminine students made the researcher select only the community of male students. The research sample was formed by 52 students with visual impairment (26 in experimental group and 26 in control group) who had mobile phones and volunteered to participate in the test. In this research, the researcher therefore asked students to attend a self-invited research. At first, 60 students with visual impairment volunteered but 8 refused to cooperate and because of the impossibility of substituting them in the middle of the research, the study proceeded with the remaining 52 students.

There was no possibility of using random selection in this study, even if the researcher had randomly selected the sample he could hardly convince all of them to cooperate. Therefore, some of the individuals were randomly selected but they were not necessarily willing to cooperate or they might have no access to mobile phones. Furthermore, due to geographical variety of the statistic population, there was no access to some of the samples. Therefore, the provinces were selected where the number of the students was more than three and they had access to mobile phones. After determining the sample size, the participants were randomly assigned to experimental and control groups (two groups of 26 persons each). In order to implement the instructional program and collect the data, after obtaining the necessary licenses and coordination of students, at first pre-test questionnaires were conducted then teaching programs including audio files of lesson 6 English high school were presented in online an method via WhatsApp application. The researcher selected this lesson because it included vocabulary, grammar, and reading comprehension. Four out of six sessions were assigned for teaching the lessons and 12 sessions were assigned to practice them. Teaching and exercises files were sent to private profiles of the individuals and to public space of virtual groups two nights in advance and in the following nights in the public spaces, there was discussion and exchange of opinions on the exercises. After the implementation of the instruction, the post-test questionnaires were carried out and the results were analyzed. The instrument to measure the learning rate of students with visual impairment, according to the subject of the course was a researcher constructed test to conduct pre-test and post-test. The test contained 30 multiple-choice questions; the questions regarding the content were approved by five high school teachers. Criterion validity was 0.63 . The reliability of this test was obtained as 0.89 using Cronbach's alpha. 


\section{RESEARCH FINDINGS}

This study examined the effect of teaching using WhatsApp on visually impaired students. It was hypothesized that teaching through mobile based virtual networks has a significant impact on learning of students with visual impairment. Shapiro-Wilks test (Table 1) was used to check for the normality of the data.

Table 1. Shapiro-Wilk test for normal distribution of scores in the pre- test and post-test learning

\begin{tabular}{llll}
\hline Evariabl & Statistics & Degrees of freedom & Level of significance \\
\hline pretest & 0.98 & 52 & $\mathbf{0 . 6 5}$ \\
Post-test & 0.87 & 52 & $\mathbf{0 . 0 6}$ \\
\hline
\end{tabular}

As shown in Table 1, the significance level of Shapiro-Wilk test was more than 0.05 and the data with a high reliability can be assumed normal. Given that the significance level of test is greater than 0.05 , the scores have a normal distribution in pre-test and post-test of learning. Levine's test was used for the assumption of homogeneity of variance. The results of this test are presented in Table 2.

Table 2. Levine's test of homogeneity of variances for the pre - test and post - test

\begin{tabular}{lllll}
\hline Variable & $\begin{array}{l}\text { Levin } \\
\text { statistic }\end{array}$ & $\begin{array}{l}\text { First Freedom } \\
\text { degree(numerator) }\end{array}$ & $\begin{array}{l}\text { Second Freedom } \\
\text { degree(denominator) }\end{array}$ & $\begin{array}{l}\text { Level of } \\
\text { significance }\end{array}$ \\
\hline pretest & 2.95 & 1 & 50 & 0.09 \\
Post-test & 3.36 & 1 & 50 & 0.07 \\
\hline
\end{tabular}

Table 2 indicates that the level of significance Levin test is more than 0.05 , and it can be said that the group variance has cohesion. Therefore, the assumption of variance cohesion is taken into consideration.

Table 3. Analysis of the assumption of homogeneity of regression slopes for learning independent covariate

\begin{tabular}{llllll}
\hline Source & $\begin{array}{l}\text { Total square } \\
\text { of third type }\end{array}$ & $\begin{array}{l}\text { Freedom } \\
\text { degree }\end{array}$ & $\begin{array}{l}\text { Mean } \\
\text { square }\end{array}$ & F & $\begin{array}{l}\text { Level of } \\
\text { significance }\end{array}$ \\
\hline $\begin{array}{l}\text { Pre-test } \\
\text { learning } \\
\text { through }\end{array}$ & 5233.80 & 2 & 2116.9 & 169.45 & 0.08 \\
mobile \\
phone
\end{tabular}

The obtained value of $\mathrm{F}$ for learning pretest and teaching through mobile phone reveals that in this case, there is no significant difference between the regression slopes of the two variables. Therefore, the assumption of regression slope homogeneity is confirmed. Therefore, all of the necessary and required assumptions to conduct the analysis test have become covariate; consequently, the data has the capability to conduct the test so as to analyze the research assumption.

Table 4. The analysis of co-variance of the two groups at post-test

\begin{tabular}{llllllll}
\hline $\begin{array}{l}\text { Source } \\
\text { of the } \\
\text { changes }\end{array}$ & $\begin{array}{l}\text { Total of } \\
\text { roots }\end{array}$ & $\begin{array}{l}\text { Freedom } \\
\text { degree }\end{array}$ & $\begin{array}{l}\text { Mean } \\
\text { of roots }\end{array}$ & $\begin{array}{l}\text { Coefficient } \\
\text { F }\end{array}$ & $\begin{array}{l}\text { level of } \\
\text { significance }\end{array}$ & $\begin{array}{l}\text { ETA } \\
\text { square }\end{array}$ & $\begin{array}{l}\text { Test } \\
\text { potentiality }\end{array}$ \\
\hline pretest & 414.86 & 1 & 414.86 & 42.78 & 0.000 & 0.47 & $\mathbf{1 . 0 0}$ \\
group & 4643.97 & 1 & 4643.97 & 478.88 & 0.000 & 0.9 & $\mathbf{1 . 0 0}$ \\
\hline
\end{tabular}




\begin{tabular}{llll}
\hline error & 475.18 & 49 & 9.7 \\
total & 38741 & 52 & \\
\hline
\end{tabular}

Table 5. Adjusted and unadjusted mean score post-test learning in experimental and control groups

\begin{tabular}{lllll}
\hline Groups & Learning mean & Standard error & Lower level & Higher level \\
\hline control & Modified 15.56 & 0.61 & 14.33 & 16.79 \\
control & Modified 15.19 & 0.99 & & \\
experimental & Modified 34.63 & 0.61 & 33.39 & 35.86 \\
experimental & Modified 35 & 0.63 & & \\
\hline
\end{tabular}

Table 5 demonstrates that there is a significant difference between learning score of the two groups in the post-test step and after the emission of the effect of the pre-test (the adjusted mean) $(\mathrm{p}<0.001)$. It was also revealed in Table 5 that the adjusted mean score of the experimental group is higher than the adjusted mean score of learning of the control group in the post-test.Teaching effect size was 0.9. The statistical strength of the test was 1.0. The level of desirable significance was $p>0.001$ which reveal the high accuracy and the sufficiency of the test. Given that the results of the test revealed that the scores of the experimental group in post-test was significantly higher than that of the control group, it can be concluded that within the limits of the experimental program, teaching through mobile based virtual network had a positive impact on the increase of learning of students with visual impairment which confirmed this assumption..

\section{RESULTS AND DISCUSSION}

The purpose of this study was to determine the effect of using a mobile based virtual network on the learning of English in students with visual impairment at second grade of high schools (second period) in Iran. The results obtained from the analysis of data revealed that teaching via mobile based virtual network had a positive impact on the learning rate of students with visual impairment. The results of the analysis of the data related to the hypothesis of the study revealed that within the framework of the limits of the experimental program, teaching through mobile based virtual network had a positive impact on the rate of learning English courses in students with visual impairment which confirmed this assumption. The result obtained according to the research hypothesis was in line with the studies carried out by Barzegar, Dehghanzadeh and MoghaddamZadeh (2012), Rezairad and Fallah (2014), Velayati et al. (2013), Sharifi Daranadi and Malmir (2012), Sarani and Ayati (2014), Enayati et al. (2014), Hossein et al. (2015), Lin (2014), Noraza et al. (2009), Nah, White, Sussex (2008), Thornton \& Houser (2005), Baki \& Akdemir (2008), Gurrero et al (2011), Suwantarathip and Orawiwatnakul (2015), Liu et al. (2014), Abbasi and Hashemi (2013), Sandeberg, Marinus and DeGeus (2011).

In reviewing the results of existing studies, the findings of other research study were aligned. It was observed that all of the researchers assumed that using mobile phone technologies has a significant effect on learning. Although the characteristics of the individual in various studies were different from the samples of this study, the results of this study were in line with those conducted previously. Different reasons are attributed to the results obtained from the hypothesis of this study. The most important ones are as follows:

1. Motivation due to the application of the mobile phone technology in instruction according to Jalilifar and Mashhadi (2013), the learners of the second language through being active, purposeful and motivated can adjust their learning behavior by selection, 
construction and creation of environments that affect successful learning. Mobile phones can easily provide these motivations for students with visual impairment.

2. Creation of cooperative students' community. Due to being portable, easy to handle and availability of mobile phones, visually impaired students can form learning groups that is not possible with the use of any other device.

3. Access to skillful teacher for teacher-student interaction: Few studies have taken into consideration one of the interesting points of using a mobile phone social network which is the possibility of having several teachers and specialist in these networks rather than having just one teacher in a classroom and jointly controlling the students' curriculum that can be helpful in giving them immediate feedback which is not practically possible in the existing classroom in our educational system.

4. Accurate arrangement of teaching content and its classification in smaller units: When students are visually impaired, presentation of much content at a time causes confusion and increases cognitive load on their reading channel. Bradley, Haynes, Cook, Boyle and Smith (2009) believed that classification of teaching content is advantageous to all learners since it omits a great deal of useless information.

5. Mobile phone is available at anytime and anywhere: For visually impaired student for whom moving in unfamiliar places is one of the biggest challenges and sometimes results in their misanthropy. Mobile phones easily fill the gap without the need for any physical movement. The mobile feature of learning provides the situation for learning regardless of time and place (Sha, Looi, Chen, Zhang, 2012; Zamani, Babri and Mousavi 2012).

6. The possibility to practice and repeat the topics at time intervals through mobile phone: Since it is possible to use mobile phones in every situation, students can go to the teaching content saved in their mobile phone whenever they desire and practice them. It is claimed that exposing students to teaching materials at well-disciplined time intervals will enhance their learning (Thornton and Houser 2001).

7. The possibility of instant feedback and continuous evaluation: As already discussed, since it is possible to hold teaching classes at the same time via mobile phones, the possibility of instant feedback and continuous evaluation of visually impaired student is provided. Teachers can easily create reminders about assignments and weekly expectations and send them, this can also enable teachers create interactive tests using short message service (Ramos, Trinona, Lambert, 2010).

Given that the results of this study demonstrated that teaching via mobile based virtual networks have a significant effect on the learning rate of the visually impaired students, it is therefore suggested that these networks should be used in teaching students with visual impairment. This issue is very important for visually impaired students and can affect their total educational performance. It is suggested that this method should be studied in different courses on various categories of students. In a separate study, the motif of the part of social networks used in teaching and learning activities can be studied.

Conducting this study only for boys is one of the shortcomings of this study. The statistic population was too scattered and access to them posed another challenge that was solved by the cooperation of coordinator colleagues of consolidated schools of the provinces. This study was conducted for English course and it cannot be generalized for other courses. In addition, since students so far have not been officially instructed through teaching technology in first session, they were confused. 


\section{REFERENCES}

Abbasi, M. \& Hashemi, M. (2013). The impacts of Using Mobile Phone on English Language Vocabulary Retention. International Research Journal of Applied and Basic Science, 4(3), 541-547.

Ally, M. \& Prieto-Blazquez, J. (2014). What is the future of mobile learning in education? Mobile learning applications in higher education. Revista de Universidad y Sociedad Del Conocimiento, 11(1), 142-151. doi http://dx.doi.org/10.7238/rusc.v11i1.2033

Alvarez, C.; Alarcon, R. \& Nussbaum, M. (2011). Implementing collaborative learning activities in the classroom supported by one-to-one mobile computing: A design-based process. Journal of Systems and Software, 84(11), 1961-1976. doi>10.1016/j.jss.2011.07.011

Baki, B. E. \& Akdemir, O. (2010). A comparison of undergraduate Students English vocabulary learning: Using mobile phone and flash Cards. Turkish Online Journal of Educational Technology, 9(3), 1-7

Barzegar, R.; Dehghanzadeh, H. \& MoghaddamZadeh, A. (2012). From E-learning to mobile learning: theoretical foundations. Journal of E-learning, 12-21.

Bradley, C.; Haynes, R.; Cook, J.; Boyle, T. \& Smith, C. (2009). Design and development of multimedia learning objects for mobile phones. In M. Ally (Ed.) Mobile learning: Transforming the delivery of education and training (pp. 157-182). Edmonton, AB, UK: Athabasca University Press.

Chuang, Y. T. (2015). SSCLS: a smartphone-supported collaborative learning system. Telematics Inform. 32(3), 463-474. http://doi.org/10.1016/j.tele.2014.10.004

Crompton, H. (2015). Research Trends in the Use of Mobile Learning in Mathematics. International Journal of Mobile and Blended Learning, 7(4), 1-15. DOI: 10.4018/IJMBL.2015100101.

Druin, A. (2009). Mobile technology for children: design for interaction and learning. USA: Morgan Kaufman publisher.

Enayati, T.; Yazdanpanah-Nouzari, A.; Behnamfar, R. \& Ghaffari-Hamdani, S. S. (2014). Mobile application providing educational content to students, Strategies. Journal of Medical Education, 7(2), 115-120.

Gedik, N.; Hanci-Karademirci, A.; Kursun, E. \& Cagiltay, K. (2012). Key instructional design issues in a cellular phone-based mobile learning project. Computers \& Education, 58(4), 1149-1159. http://doi.org/10.1016/j.compedu.2011.12.002

Guerrero, L. A.; Ochoa, S. \& Collazos, C. (2010). A mobile learning tool for improving grammar skills. Social and behavioral science,2(2), 1735-1739. DOI: 10.1016/j.sbspro.2010.03.975

Guler, C.; Kilıc, E. \& Cavus, H. (2014). A comparison of difficulties in instructional design processes: Mobile vs. desktop. Computers in Human Behaviour, 39, 128-135. http://doi.org/10.1016/j.chb.2014.07.008

Hodges, C., \& Prater, A. (2013). Teachers Comment on Horizon Report. 35th Annual Proceedings of the Association for Educational Communications and Technology. Retrieved June 5, 2015, from http://digitalcommons.georgiasouthern.edu/leadershipfacpubs/30/.

Hussein, A. H.; AlHaisoni, M. M.; Bany Mohammed, A. A. \& Fakrudeen, M. (2015). MLearning for Blind Students Using Touch Screen Mobile Apps Case Study- Special Education in Hail. International Journal of Computer Science and Information Security, 13(12), 82-88. 
Keating, E.; Nagai, E.; Hadder, N. \& Kowalsky, J. (2007). The Role of the Mobile Phone in the Welfare of Aged and Disabled People. Retrieved June 12, 2016, from https://pdfs.semanticscholar.org/31f7/cf6b4fca39e6a51334e23674659597c4f6ec.pdf

Kukulska-Hulme, A.; Sharples, M.; Milrad, M.; Arnedillo-Sánchez, I.; \& Vavoula, G. (2009). Innovation in mobile learning: A European perspective. International Journal of Mobile and Blended Learning, 1(1), 13-35. DOI: 10.4018/jmbl.2009010102

Lan, Y. F., \& Sie, Y. S. (2010). Using RSS to support mobile learning based on media richness theory. Computers \& Education, 55(2), 723- 732. http://doi.org/10.1016/j.compedu.2010.03.005

Laurillard, D. (2007). Pedagogical forms for mobile learning. In N. Pachler (Ed.), Mobile learning: To-wards a research agenda. London, UK: WLE Centre.

Lin, C-C. (2014). Learning English reading in a mobile-assisted extensive reading program. Computers \& Education 78, 48-59. http://doi.org/10.1016/j.compedu.2014.05.004

Liu, M.; Navarrete, C.; Maradiegue, E. \& Wivagg, J. (2014). Mobile Learning and English Language Learners: A Case Study of Using iPod Touch As a Teaching and Learning Tool. Journal of Interactive Learning Research, 25(3), 373-403. Chesapeake, VA: Association for the Advancement of Computing in Education (AACE).

Martin, F. \& Ertzberger, J. (2013). Here and now mobile learning: An experimental study on the use of mobile technology. Computers \& Education, 68, 76-85. http://doi.org/10.1016/j.compedu.2013.04.021

Martin, R.; McGill, T. \& Sudweeks, F. (2013). Learning Anywhere, Anytime: Student Motivators for M-learning. Journal of Information Technology Education: Research, 12, 51-67.

Mohammed, N. M. N.; Mamat, M. N. \& Isa, P. M. (2012). M-learning in Malaysia: Challenges and strategies. Social and Behavioral Sciences, 67, 393-401. http://doi.org/10.1016/j.sbspro.2012.11.343

Nah, K.C., White, P., \& Sussex, R. (2008). The potential of using a mobile phone to access the Internet for learning EFL listening skills within a Korean context. ReCALL, 20(3), 331-347. DOI: https://doi.org/10.1017/S0958344008000633

Noraza, M. N.; Mohd, I.; Hamzeh, A. \& Mohamed, A. E. (2010). The Mobile Learning Environment for the in-service school administrators. Social and behavioral science, 7 , 671-679. http://doi.org/10.1016/j.sbspro.2010.10.091

Pearson Education. (2014). Pearson Student Mobile Device Survey 2014. Retrieved march 26, 2016, from http://www.pearsoned. com/wp-content/uploads/Pearson-K12-StudentMobile-Device-Survey-050914-PUBLIC-Report.pdf.

Prajapaty, M. \& Patel, J. M. (2014). The Factors Influencing in Mobile Learning Adoption: A Literature Review Manoj. International Journal of Application or Innovation in Engineering \& Management, 3(9), 133-138.

Preece, J. (2000). Online communities: designing usability, supporting sociability. Chichester, UK: Wiley Press.

Ramos, A., \& Trinona, J. (2010). Mobile technology in non-formal distance education. In J. Baggaley \& T. Belawati (Eds.), Distance education technologies in Asia. New Delhi: Sage India.

Rikala, J. (2014). Developing a Cohesive Mobile Learning Framework. Developing a Cohesive Mobile Learning Framework. Proceedings of the European Conference on eLearning; 2014, p720.

Roblyer, M. D. \& Doering, A. H. (2010). Integrating educational technology into teaching (5th ed.). New York, NY: Allyn \& Bacon. 
Sandberg, J.; Maris, M., \& DeGeus, K. (2011). Mobile English learning: An evidence-based study with fifth graders. Computers \& Education, 57(1), 1334-1347. http://doi.org/10.1016/j.compedu.2011.01.015

Sarani, H. \& Ayati, M. (2014). Effects of Cell Phone (SMS) on students learning English vocabulary and attitude. Research on Curriculum, 13(40), 48-60.

Sha, L.; Looi, C. K.; Chen, W., \& Zhang, B. H. (2012). Understanding mobile learning from the perspective of self-regulated learning. Journal of Computer Assisted Learning, 28(4), 366-378. DOI: 10.1111/j.1365-2729.2011.00461.x.

Sharifi-Daramadi, P. (2000). Psychology and education of blind children. Tehran: Goftemane Khalagh.

Sharifi-Daramadi, P. \& Malmir, M. (2012). Review and compare auditory information processing speed and visual impairment in adolescents 14-16 years Able to see in Tehran. Special Psychology, 6 (1), 47-60.

Sharples, M. (2000). The design of personal mobile technologies for lifelong learning. Computers \& Education, 34(3-4), 177-193. http://doi.org/10.1016/S03601315(99)00044-5

Sparrowhawk, A. \& Hilde, Y. (2004). ICT and special educational needs. UK: McGraw-Hill Education.

Suwantarathip, O. \& Orawiwatnakul, W. (2015). Using Mobile-Assisted Exercises to Support Students' Vocabulary Skill Development. The Turkish Online Journal of Educational Technology, 14 (1), 163-171.

Thornton, P. \& Houser, C. (2001). Learning on the Move: Vocabulary Study via Email and Mobile Phone SMS. In C. Montgomerie \& J. Viteli (Eds.), Proceedings of EdMedia: World Conference on Educational Media and Technology 2001 (pp. 1896-1897). Association for the Advancement of Computing in Education (AACE).

Thornton, P., \& Houser, C. (2005). Using mobile phones in English Education in Japan. Journal of Computer Assisted Learning, 21, 217-228. DOI: 10.1111/j.13652729.2005.00129.x .

Velayati, E. (2012). Effects of video games on learning, retention and academic achievement in students with intellectual disability second grade elementary math concepts, Unpublished master's thesis, University of Allameh Tabataba'i

Zamani, B. E.; Babri, H. \& Mousavi, S. (2012). Factors related to the attitudes of medical students to embrace learning through mobile phones using the technology acceptance model. The Journal of Medical Education Development, 10(2), 110-117.

Zaraii Zavaraki, I. \& Jafarkhani, F. (2012). Information and communication technology applications to support students with special educational needs. Exceptional education Journal. 45-56. 